Nama : Putri Anatysia Cumalasari

Nrp : 130217205

$\mathrm{KP}: \mathrm{B}$

\title{
The Development of Digital Economy in Indonesia
}

\author{
Ahmad Zafrullah Tayibnapis, Lucia E. Wuryaningsih, Radita Gora
}

In the era of globalization, the development of technology is very rapid from year to year around the world. Advanced technology helps people to carry out their activities practically, especially in Indonesia. Using mobile technology makes it easier for work or daily activities that don't take up time and effort so that it becomes more efficient and effective. With the variety of human activities in urban and rural areas, with the encouragement of technology, all humans must follow these changes by living more practically, especially in interacting. There are various factors in the development of technology such as the internet, sophisticated mobile phones and e-commerce. So business people can carry out buying and selling activities and transactions online. Utilizing technology in the business world will have a positive impact on businesses and consumers in obtaining information about the products to be purchased through online sites.

Mobile banking is generally defined as an m-commerce application file, which is supported by mobile technology and products to enable consumers to process banking services on mobile devices, including smartphones, tablets, smart watches, and other smart technologies. Internet Banking is a service facility provided to customers to carry out banking transactions via the internet network and cellular technology. Services like this can be used by consumers anywhere and anytime, because these services are through cellular technology. This internet banking service is accessed 
remotely so that consumers do not need to be served by tellers and customer service. This is in line with the behavior of consumers who want services without having to be physically present at the bank office, insurance office, or finance company. The availability of digital banking services and products is highly appreciated by customers, both individuals and businesses, especially Micro, Small and Medium Enterprises (MSMEs).

Financial services in digital banking are well developed, such as internet banking, mobile banking, AMS banking, ATMs, e-money, phone-banking, payment galleries, branchless banking, online debit, digital outlets, virtual credit cards, cash management systems, EDC, mobile branches, mobile accounts, and smartphone-based financial applications. It is important to note that Indonesia's future economic growth requires a strong and stable financial sector of $6 \%$ per year. This means that banking, insurance, capital markets, and start-up companies must be encouraged so that annual credit growth is no longer in the range of $10-12 \%$. This is intended so that the capacity of the financial sector can increase five times from the current position as achieved by Singapore and Thailand. The public is also familiar with e-commerce which can be accessed through wireless handheld devices, such as cell phones, handheld computers, and personal digital assistance whose activities refer to online. Based on data from KOMINFO and BAREKSA (2016), world e-commerce transactions reached 20.2\% per year. E-commerce transactions in Indonesia reached IDR 200 trillion in 2015 and is predicted to reach IDR 1,850 trillion in 2020 or an increase of 9 times in 5 years with an impact of $12 \%$ on GDP. The online business has now reached more than Rp. 144 trillion in transactions, and will grow rapidly thanks to the support of the $4 \mathrm{G}$ internet network and the positive response from the public regarding digital technology. E-money has experienced rapid growth since its introduction in 2008, both in terms of the number of instruments in circulation, number of transactions, transaction value, and number of readers. The government even requires road users to make payments using e-money, prepare electronic money readers for up to 20 types of 
electronic money, and provide more counters for e-money refills so that users have a lot of convenience.

All banks have more than one digital financial product and claim that the products offered are superior to similar products released by competitors. Each bank strives to offer innovative and technologically advanced digital products from biometry to artificial intelligence and enhance its security system beyond a one-time password despite the consequences of large-scale investment in infrastructure procurement and promotion. Experience in countries such as the United States and China has proven how important it is to create open innovation that can be easily understood by different cultures and innovation processes that allow input from multiple sources, both internal and external, by building partnerships that have understanding and competence in financial technology. Digital banking can even be transferred to competent parties with the consideration that it does not have competent human resources. The application of the sharing economy in the United States is worth watching, namely the lending business that continues to grow without going through bank institutions using a number of platforms, such as Lending Club, Prosper, SoFi, and Zopa. The bureaucratic approach that is not convoluted, including without collateral or collateral, makes this platform thrive. In fact, the amount of credit has reached US \$ 2.5 billion since its introduction in 2009. This shows how much public trust in this platform is. However, these platforms can eat away at traditional bank revenues if they don't innovate.

The current global era until 2030 is different from previous years because advanced mobility technology is able to create new ecosystems and transform new ones. way of life. Virtual reality and augmented reality games can help and transform the way individuals work to be more collaborative, more productive, and more motivated to reach top careers. Currently, in 2018, there are several trends that are rapidly developing, such as better payment options, smartphone optimization, fast delivery of goods, use of chat robots to answer customer questions, and use of 
customer loyalty coupons to increase sales and visitors. Likewise, the increasing number of mobile phone users is expected to reach more than 100 million people in the near future. Some people must think about how to secure privacy and trust when using online transactions or mobile banking. So related to such matters, banking companies will protect privacy and promise consumer confidence in using the online system. With the development of information systems, it can change consumer behavior with enjoyment, entertainment and joy, hinting at the hedonic values contained in cellular technology. 